\title{
Bank-Specific and Macroeconomic Determinants of Commercial Banks Profitability in Ghana
}

\author{
Ibrahim Nandom Yakubu \\ University of Liverpool Management School, UK \\ E-mail: kassiibrahim@gmail.com
}

Received: Aug. 24, 2016

Accepted: Sept. 7, 2016

Published: Sept. 12, 2016

doi:10.5296/ifb.v3i2.9936

URL: http://dx.doi.org/10.5296/ifb.v3i2.9936

\begin{abstract}
This study examines the influence of bank-specific and macroeconomic factors on commercial banks profitability in Ghana. The study employed the ordinary least square regression model to analyse the data obtained from the annual financial statements of five commercial banks from 2010 to 2015. The empirical results suggest that bank size, liquidity, capital adequacy, asset management, expense management, and real interest rate are positively related to profitability. GDP growth and inflation rate on the other hand, are related negatively to profitability. However, only bank size, liquidity, and expense management have a significant effect on commercial banks profitability. It can be observed that commercial banks profitability in Ghana is largely determined by bank-specific factors, whereas macroeconomic factors have an insignificant impact on banks profitability for the period considered. Therefore, it is crucial for management of commercial banks in Ghana to efficiently manage the factors that contribute to their profitability in order to enhance superior performance.
\end{abstract}

Keywords: Profitability, Commercial banks, Determinants, Ghana 


\section{Introduction}

The strength and sustainability of a county's banking system serve as one of the key determinants of its economic growth and development. Ghana's banking sector is one of the services sectors contributing to the growth of the economy. It plays a crucial role in employment, human resource transfer, and capital mobilisation.

In recent years, the banking sector has undergone significant transformation and continue to develop new regulations and guidelines with the aim of maintaining stability. The sector has also experienced a significant development after the enactment of the Financial Sector Adjustment Programme (FINSAP) in 1988 under the Economic Recovery Programme in the 1980s (Owusu-Antwi, 2011). The FINSAP was implemented to help mitigate the challenges faced by banks in Ghana in terms of low profitability, the low level of innovation and technology, low competition, and liquidity challenges (Anin, 2000). The economic reforms have also helped in the financial sector liberalisation in Ghana leading to an increase in the number of banks in the country. According to the 2014 annual report of the Ghana Banking Survey, 28 universal banks operate in Ghana including domestic and foreign banks, 58 non-banking institutions, and 137 rural and community banks.

The increasing number of banks in Ghana has brought about efficiency and competition in the banking sector which has led to growth in profitability of banks, especially commercial banks in the country. Commercial banks take a share of $75 \%$ of the total assets of Ghana's financial system (IMF Country Report, 2011). The growing trend in banks profitability has attracted the attention of academic researchers and policy makers in the fields of economics and finance. It is therefore imperative to investigate to find out what factors influence banks profitability in Ghana. This study uses bank level data which spans from 2010-2015 comprising of five selected commercial banks in Ghana to find out the factors that determine commercial banks profitability.

\section{Literature Review}

Bank profitability according to several studies is measured using Return on Assets (ROA), Return on Equity (ROE), and Net Interest Margin (NIM). The determinants of profitability of banks are usually classified as internal and external determinants. Husni (2011) explained that the internal determinants refer to the factors that affect the cost and revenue of banks and are within the control of management. Some studies further classified these internal factors into financial statement factors and non-financial statement factors. The external determinants of bank profitability on the other hand, refer to the factors that originate from macroeconomic conditions (for example; GDP, Inflation, Exchange rate, etc.) and industry related factors that cannot be controlled by banks, but they have a significant impact on banks profitability (Kraka \& Ameyaw, 2010). The empirical literature as discussed below explore both the internal and external factors that determine the profitability of banks.

Ali et al. (2011) made an assessment on the factors determining commercial banks profitability in Pakistan using Return on Assets (ROA) and Return on Equity (ROE) as measures of profitability. Employing a regression analysis, the results revealed that efficient 
bank asset management and economic growth are significant determinants of bank profitability when measured by ROA and ROE. The results also indicated that high credit risk and capitalisation insignificantly influence profitability in terms of ROA. The operational efficiency of banks impacts significantly on bank profitability in terms of ROE.

Athanasoglou et al. (2006) used external and bank-specific factors affecting bank profitability to examine the determinants of profitability in Greek banks for the period 1985 to 2001. The findings presented macroeconomic variables (inflation, GDP, interest rate, taxation) and bank-specific factors to have a positive impact on bank profitability. The results also showed that industry specific factors do not influence bank profitability. Similarly, Molyneux \& Thornton (1992) established that interest rate by Central bank, inflation, and GDP are positively related to bank profitability.

Employing a panel data regression analysis, Al-Haschimi (2007) examined the determinants of bank profitability in 10 Sub-Sahara African countries. Using Net Interest Margin (NIM) as a measure of bank profitability, the study reported credit risk and operating efficiencies as the significant factors influencing bank profitability. Macroeconomic factors in his study, have limited impact on bank profitability in Sub-Sahara Africa. Also in Sub-Sahara Africa, Flamini et al. (2009) used cross-sectional data involving a sample of 389 banks to determine bank profitability in 41 Sub-Sahara African countries. By applying the Ganger-Causality test, the results found that bank size, diversification, and private ownership contribute to the higher profitability of banks while credit risk contributes negatively to bank profitability.

Saunders \& Schumacher (2000) in an analysis of the determinants of profitability (measured by Net Interest Margin) in six countries in the EU and US, used a time series data for the period 1988 to 1995. By applying the Saunders and Ho model, the findings revealed that interest rate restriction on bank deposits, capital to asset ratio, and reserve requirements impact significantly on bank profitability.

Zuttah (2004) made a comparative analysis on the performance of banks in Ghana using Standard Chartered Bank and Ghana Commercial Bank as units for the analysis. His study used bank level data for the period 1990-2003. The findings of the study established that operational procedures of bank management significantly impact on the performance of the two banks considered.

Almazari (2011) analysed the financial performance of 7 banks in Jordan for the period 2005 to 2009. Using ROA and Net Income size as measures of bank profitability, the results found that higher credits, bank deposits, and shareholders' equity do not depict banks profitability. The results also found that asset utilisation, asset size, and operational efficiency are positively correlated with banks profitability.

Al-Tamimi \& Hussein (2010) in determining the factors affecting the financial performance of banks in UAE from 1996-2008, used Return on Assets and Return on Equity as measures of bank profitability. The research concluded that liquidity and bank concentration significantly determine the financial performance of Conventional banks in the UAE.

Sufian (2009) assessed the determinants of commercial banks performance in Malaysia 
employing bank level data covering 2000-2004. The findings of the analysis revealed that higher credit risk and loan concentration negatively affect bank profitability. The results further presented higher level of bank capitalisation, higher operational expenses, and higher net income as factors impacting positively on bank profitability.

Petria et al. (2015) in an assessment of the determinants of bank profitability in EU-27 over the period 2004 to 2011, used ROA and ROE as bank profitability measures. The empirical results indicate that credit and liquidity risk, diversification of operations, competition, and GDP have a positive effect on bank profitability. However, only competition significantly determines the variations in bank profitability in the EU-27.

Gyamerah \& Amoah (2015) assessed the determinants of local and foreign banks profitability in Ghana using bank-specific and macroeconomic factors. The research concluded that bank size and credit risk have a positive relationship with profitability while cost management and profitability are inversely related.

Tariq et al. (2014) made an empirical analysis of the determinants of commercial banks profitability in Pakistan from 2010-2014 using regression analysis. The results reported that asset quality, bank size, and capitalisation impact positively on the higher profitability of banks. Also in Pakistan, Gul \& Zaman (2011) examined the determinants of bank profitability in 10 top banks using internal factors affecting profitability. The results asserted that bank assets, total loans, equity and total deposits impact significantly on bank profitability.

\section{Methodology}

\subsection{Sample Size and Data}

Five commercial banks were selected for this study based on the availability of data. The selected banks were GCB Bank Limited, CAL Bank Limited, Standard Chartered Bank Ghana Limited, Ecobank Ghana Limited, and Societe Generale Ghana. The main sources of data for this study comprised mainly secondary data. The data for the dependent variable and the bank-specific variables was obtained from the annual financial statements of the selected banks. The data for the macroeconomic factors was obtained from the World Bank Development Indicators and the Bank of Ghana.

\subsection{Description of Variables}

From the results of the literature review, several factors have been identified as measures and indicators of bank profitability. This study used one dependent variable and eight independent variables consisting of both bank-specific and macroeconomic factors determining banks profitability.

\subsubsection{Dependent Variable}

Most studies conducted on bank profitability (for example; Khrawish, 2011; Qin \& Dickson, 2012; Flamini et al., 2009) have used ROA, ROE, and Net Interest Margin (NIM) as the possible profitability measures of banks. In this study, ROA is used as a measure of bank profitability. ROA refers to the ratio of Net Income divided by Total Assets. In general, the 
literature on banks profitability has emphasised greatly on ROA as the best measure of profitability as it makes an assessment of the efficiency and effectiveness of the bank management in transforming assets into profits (Obamuyi, 2013).

\subsubsection{Independent Variables}

\subsubsection{Bank-Specific Variables}

Bank Size: The total assets of banks are usually used as a measure of bank size. According to Ben Naceur \& Goaied (2008), the ability of banks to benefit from economies of scale depends on its size. In general, bank size is expected to have a positive influence on bank profitability (Smirlock, 1985).

Liquidity: Banks are mandated to maintain a certain level of liquid assets in running their activities, and insufficient liquidity may lead to banks failure (Rasiah, 2010). Liquidity is measured by the ratio of loans to deposits. According to Bourke (1989), liquidity is positively related to bank profitability.

Capital Adequacy: This indicates the capital strength of a bank measured by the ratio of equity to total assets. Higher capital adequacy ratio depicts the ability of a bank to finance its activities with less external funding. Capital adequacy ratio and profitability are expected to relate positively (Berger, 1995).

Asset Management: The ratio of operating income to total assets is used as a proxy of asset management. Efficient asset management is expected to have a positive influence on bank profitability.

Expenses Management: The ratio of operating expenses to total assets is used as a measure of expenses management. Effective management of expenses will lead to higher profitability. According to Athanasoglou et al. (2006), profitability and expenses management are expected to have a negative relationship.

\subsubsection{Macroeconomic Variables}

GDP: GDP measures the economic activity of a country. Obamuyi (2013) stated that GDP defines the favourable and unfavourable economic conditions of a country which have an impact on banks deposits and loans. This study used the annual GDP growth as a proxy for GDP. GDP growth is expected to have a positive relationship with profitability.

Inflation Rate: Inflation rate in a country contributes to the variations of bank profitability (Ravell, 1979). According to Rasiah (2010), central banks on their effort to control inflation, tend to increase the lending rate which impacts on bank profitability. Inflation and profitability may relate positively or negatively (Perry, 1992).

Real Interest Rate: The real interest rate is expected to impact positively on bank profitability. This is because when the real interest rate by the central bank increases, the lending rate by commercial banks to customers also increases which contribute to profitability. 


\subsection{Model Specification and Analytical Approach}

The study used multiple regression analysis to establish the relationship and the significance of the independent variables on bank profitability. The regression model is presented as:

$$
R O A_{i t}=a_{0}+b_{1} B S i z e_{i t}+b 2 L Q_{i t}+b_{3} C A_{i t}+b_{4} A M_{i t}+b_{5} E M_{i t}+b_{6} G D P_{i t}+b_{7} \operatorname{Inf}_{i t}+b_{7} I r+\varepsilon
$$

where the subscript represents banks $i$ in year $t$. The symbol $a$ refers to the intercept and $b$ refers to the regression parameters. $R O A$ is the dependent variable which represents profitability. Bank Size, Liquidity, Capital adequacy, Asset Management, Expenses Management, GDP, Inflation, and Real Interest Rate are represented by BSize, $L Q, C A, A M$, $E M, G D P, I n f$, and Ir respectively. $\varepsilon$ refers to the error term.

\section{Analysis and Results}

\subsection{Results of the Descriptive Statistics and Correlation Analysis}

Before estimating the determining factors of banks profitability, the study carried out descriptive statistics on the dependent and independent variables as shown below:

Table 1. Descriptive statistics

\begin{tabular}{|l|l|l|l|l|}
\hline Variables & Mean & Stand Dev. & Minimum & Maximum \\
\hline ROA & 11.50 & 2.94 & 6.3 & 19.0 \\
\hline Bank Size & 2.59 & 1.53 & 0.51 & 6.70 \\
\hline Liquidity & 63.62 & 23.88 & 23.1 & 122.7 \\
\hline Capital Adequacy & 14.0 & 2.81 & 7.2 & 18.4 \\
\hline Asset Management & 13.44 & 2.34 & 8.8 & 19.5 \\
\hline Expenses Management & 6.6 & 1.88 & 3.9 & 10.2 \\
\hline GDP Growth & 7.7 & 3.49 & 3.9 & 14.0 \\
\hline Inflation Rate & 12.0 & 3.18 & 8.7 & 17.1 \\
\hline Real Interest Rate & 17.5 & 12.67 & 0 & 28.0 \\
\hline
\end{tabular}

From Table 1, the descriptive statistics shows the average (mean), standard deviation, minimum and maximum values of each variable. As presented in the results, commercial banks in Ghana have an average ROA of $11.5 \%$ with an estimated minimum value of $6.35 \%$ and maximum value of $19 \%$. Bank size has the lowest mean and standard deviation of 2.59 and 1.53 respectively. The standard deviation value of bank size is an indication of less fluctuation in the value of total assets of commercial banks in Ghana. On an average, the capital adequacy ratio is estimated at $14 \%$ with a minimum and maximum values of $7.2 \%$ and $18.4 \%$ respectively. The average capital adequacy ratio of $14 \%$ exceeds the $10 \%$ minimum capital adequacy requirement imposed on commercial banks by the Bank of Ghana. This means that commercial banks in Ghana maintain more capital than the amount the Central Bank requires. Holding more capital could also imply that commercial banks in Ghana are not willing to make risky investments. From the results, the average liquidity ratio amounts to 
$63.62 \%$. This value largely exceeds the $28.3 \%$ minimum liquidity requirements of commercial banks as at 2013. The liquidity ratio also has the highest standard deviation which depicts the massive fluctuation in liquidity of commercial banks in Ghana. With the macroeconomic variables, the average values of GDP, inflation, and real interest rate have been estimated at $7.7 \%, 12 \%$ and $17.5 \%$ respectively.

In order to establish how the independent variables are associated, a correlation analysis was carried out as presented in Table 2 below:

Table 2. Correlation analysis

\begin{tabular}{|l|l|l|l|l|l|l|l|l|}
\hline & BSize & LQ & CA & AM & EM & GDP & Inf & Ir \\
\hline BSize & 1 & & & & & & & \\
\hline LQ & -0.201 & 1 & & & & & & \\
\hline $\boldsymbol{C A}$ & -0.082 & 0.427 & 1 & & & & & \\
\hline $\boldsymbol{A M}$ & 0.561 & -0.267 & 0.254 & 1 & & & & \\
\hline $\boldsymbol{E M}$ & 0.073 & -0.523 & -0.129 & 0.563 & 1 & & & \\
\hline $\boldsymbol{G D P}$ & -0.518 & -0.281 & -0.361 & -0.630 & -0.056 & 1 & & \\
\hline Inf & 0.587 & 0.207 & 0.300 & 0.594 & 0.111 & -0.897 & 1 & \\
\hline Ir & 0.564 & 0.289 & 0.351 & 0.491 & -0.085 & -0.718 & 0.636 & 1 \\
\hline
\end{tabular}

As shown in Table 2 above, there exist weak correlation among the variables. According to Kennedy (2003), a high correlation exists when the correlation coefficient exceeds 0.80 or 0.90. Also, Bryman \& Cramer (2002) stated that there exists multicollinearity when the correlation coefficient is more than 0.80 . Therefore, the low correlation values in the results of the correlation analysis show the absence of multicollinearity among the independent variables.

\subsection{Empirical Results on the Determinants of Banks Profitability}

Table 3. Summary of regression analysis

\begin{tabular}{|l|l|l|l|l|}
\hline Variable & Coefficients & Standard Error & t Stat & Sig. \\
\hline (Constant) & -4.814 & 6.185 & -0.778 & 0.445 \\
\hline Bank Size & 0.897 & 0.367 & 2.448 & 0.023 \\
\hline Liquidity & 0.042 & 0.021 & 2.027 & 0.046 \\
\hline Capital Adequacy & 0.212 & 0.151 & 1.399 & 0.176 \\
\hline Asset Management & 0.416 & 0.306 & 1.360 & 0.188 \\
\hline Expenses Management & 1.033 & 0.275 & 3.753 & 0.001 \\
\hline GDP Growth & -0.014 & 0.254 & -0.055 & 0.957 \\
\hline Inflation Rate & -0.357 & 0.246 & -1.450 & 0.162 \\
\hline Real Interest Rate & 0.020 & 0.041 & 0.478 & 0.637 \\
\hline $\begin{array}{l}\mathrm{R}^{2}=0.765 . \text { Adjusted } \mathrm{R}^{2}=0.676 . \mathrm{F}(8,21)=8.562 . \text { Prob (F-Statistic) }=0.00004 . \\
\text { Durbin-Watson Stat }=2.46 .\end{array}$ & & \\
\hline
\end{tabular}


From the regression results in Table 3 above, the $\mathrm{R}^{2}$ of 0.765 indicates that the independent variables fit well with the dependent variable in the model. The $\mathrm{R}^{2}$ value also shows that about $76.5 \%$ variation in commercial banks profitability is caused by changes in the independent variables. Overall, the regression model is statistically significant, $F=8.562$, $p=0.00004$, hence supporting the fact that the bank-specific and macroeconomic factors used in the model are crucial factors explaining the profitability of commercial banks in Ghana. The Durbin-Watson Statistics of 2.46 is an indication of no autocorrelation among the independent variables, which makes the model more reliable.

From the regression results, the coefficient of bank size is positive and statistically significant, indicating a direct and significant relationship between bank size and profitability. The positive coefficient of bank size means that, as commercial banks increase in assets size, profitability also increases. This finding is in line with the results of Gyamerah \& Amoah (2015), Ally (2014), and Ali et al. (2011) who established that, a strong relationship exists between bank size and profitability.

The coefficient of liquidity which is measured by the ratio of loans to deposits has a positive and significant impact on banks profitability. This agrees with the findings of Bourke (1989) and Ally (2014) who presented a positive and significant relationship between liquidity management and profitability of banks.

As expected, capital adequacy has a positive relationship with profitability though it is not significant. The positive coefficient of capital adequacy indicates that the more capital banks reserve, the more profits they are able to generate. This is in agreement with the statement by Athanasoglou et al. (2006) who asserted that banks who maintain adequate capital are able to take up business opportunities more rapidly, use high technology and effectively deal with problems arising from unexpected losses, hence contributing to higher profits.

Asset management and expense management also have a positive relationship with banks profitability, although asset management is not significant. Expense management however, has a significant impact on banks profitability, indicating that efficient administration of banks' expenses through the reduction in operational cost enhance the profitability of commercial banks in Ghana. This agrees with the results of Obamuyi (2013).

As revealed in the estimation, GDP growth has a negative and insignificant impact on banks profitability which does not conform to the expectation of this study. The negative effect of GDP on bank profitability may be as a result of non-performing loans due to an economic recession. That is, commercial banks may have to write off non-performing loans when the Ghanaian economy goes bad, hence affecting their profits.

The estimated coefficient of inflation is negative, indicating its inverse relationship with profitability. Inflation is also found to have an insignificant relationship with banks profitability. This is consistent with the analysis of Ally (2014) who discovered a negative and insignificant effect of inflation on banks profitability.

Expectedly, the real interest rate has a positive relationship with profitability though it is insignificant. The positive coefficient indicates that commercial banks increase in profits as 
interest rate increases. The positive but insignificant relationship of the real interest rate on bank profitability conforms to the findings of Staikouras \& Wood (2011).

\section{Conclusion}

The Ghanaian banking sector has undergone significant transformation in recent years which has led to stability and growth in profits of banks in the country. This study assessed the factors that influence commercial banks profitability in Ghana taking into consideration bank-specific and macroeconomic factors. After the empirical analysis, the study concluded that all the variables have the right coefficients as expected, except GDP growth and expense management. The results established that bank size, liquidity, capital adequacy, asset management, expense management, and interest rate have a positive relationship with profitability. GDP growth and inflation on the other hand, related negatively to profitability. With regards to the significant factors impacting on commercial banks profitability, only bank size, liquidity, and expense management were found to be significant. Overall, the empirical findings indicate that the profitability of commercial banks in Ghana is largely influenced by bank-specific factors, whereas macroeconomic factors impact insignificantly on banks profitability. The results of this study offer important policy implications. For bank management, it is hoped that this study will serve as a guide in the formulation and implementation of effective strategies and better policies which may enhance the superior performance of commercial banks in Ghana.

\section{References}

Al-Hashimi, A. (2007). Determinants of bank spreads in Sub-Saharan Africa. IMF Draft Working Paper, 05/06.

Ali, K., Akhtar, M. F., \& Ahmed, H. Z. (2011). Bank-specific and macroeconomic indicators of profitability-empirical evidence from the commercial banks of Pakistan. International Journal of Business and Social Science, 2(6), 235-242.

Ally, Z. (2014). Determinants of banks' profitability in a developing economy: Empirical evidence from Tanzania. European Journal of Business and Management, 6(31), 363-375.

Almazari, A. A. (2011). Financial performance evaluation of some selected Jordanian commercial banks. International Research Journal of Finance and Economics, 68(8), 50-63.

Al-Tamimi, H., \& Hussein, A. (2010). Factors influencing performance of the UAE Islamic and conventional national banks. Global Journal of Business Research, 4(2), 1-9.

Anin, T. E. (2000). Banking in Ghana. Accra: Woeli Publication Services.

Athanasoglou, P., Delis, M., \& Staikouras, C. (2006). Determinants of bank profitability in the south eastern European region. Social Science Electronic Publishing, 1-17.

Ben Naceur, S., \& Goaied, M. (2008). The determinants of commercial bank interest margin and profitability: Evidence from Tunisia. Frontiers in Finance and Economics, 5(1), 106-130. 


\section{Macrothink}

Berger, A. N. (1995). The relationship between capital and earnings in banking. Journal of Money, Credit and Banking, 27(2), 432-456. http://dx.doi.org/10.2307/1913103

Bourke, P. (1989). Concentration and other determinants of bank profitability in Europe, North America and Australia. Journal of Banking \& Finance, 13(1), 65-79. http://dx.doi:10.1016/0378-4266(89)90020-4

Bryman, A., \& Cramer, D. (2002). Quantitative data analysis with SPSS release 10 for windows: A guide for social scientists. New York: Routledge.

Flamini, V., Schumacher, M. L., \& McDonald, M. C. A. (2009). The determinants of commercial bank profitability in Sub-Saharan Africa. International Monetary Fund, 9(15), $1-30$.

Gul, S., Irshad, F., \& Zaman, K. (2011). Factors affecting bank profitability in Pakistan. The Romanian Economic Journal, 39(14), 61-89.

Gyamerah, I. A., \& Amoah, B. A. B. (2015). Determinants of bank profitability in Ghana. International Journal of Accounting and Financial Reporting, 5(1), 173-187. http://dx.doi.org/10.5296/ijafr.v5i1.7368

Husni, A. (2011). Determinants of commercial banks performance evidence from Jordan. International Research Journal of Finance and Economics, 149-158.

International Monetary Fund. (2011). IMF staff country reports. [Online] Available: http://dx.doi.org/10.5089/9781463929268.002

Kennedy, P. (2003). A guide to econometrics. Cambridge: MIT press.

Khrawish, H. A. (2011). Determinants of commercial banks performance: Evidence from Jordan. International Research Journal of Finance and Economics, 81, 148-159.

Krakah, A., \& Ameyaw, A. (2010). The determinants of Bank's profitability in Ghana, the case of merchant bank Ghana limited (MBG) and Ghana commercial bank (GCB). Unpublished MBA Thesis, Blekinge Institute of Technology.

Molyneux, P., \& Thornton, J. (1992). Determinants of European bank profitability: A note. $\begin{array}{lllll}\text { Journal of Banking } \& \quad \text { Finance, } & 16(6), & 1173-1178 .\end{array}$ http://dx.doi:10.1016/0378-4266(92)90065-8

Obamuyi, T. M. (2013). Determinants of banks' profitability in a developing economy: Evidence from Nigeria. Organizations and Markets in Emerging Economies, 2, 97-111.

Owusu-Antwi, G. (2011). Impact of financial reforms on the banking system in Ghana. International Business \& Economics Research Journal (IBER), 8(3), 77-100. http://dx.doi.org/10.19030/iber.v8i3.3116

Perry, P. (1992). Do banks gain or lose from inflation? Journal of Retail Banking, 14(2), 25-31. http://dx.doi.org/10.4236/ojacct.2013.22005 
Petria, N., Capraru, B., \& Ihnatov, I. (2015). Determinants of banks’ profitability: Evidence from EU 27 banking systems. Procedia Economics and Finance, 20, 518-524. http://dx.doi.org/10.1016/S2212-5671(15)00104-5

Pwc. (2014). 2014 Ghana banking survey: The future of banking in Ghana. What's next? [Online] Available: http://www.pwc.com/gh/en/publications/index.jhtml

Qin, X., \& Dickson, P. (2012). Commercial banks profitability position: The case of Tanzania. International Journal of Business and Management, 7(13), 136. http://dx.doi.org/10.5539/ijbm.v7n13p136

Rasiah, D. (2010). Theoretical framework of profitability as applied to commercial banks in Malaysia. European Journal of Economics, Finance and Administrative Sciences, 19(19), 75-97.

Revell, J. (1979). Inflation and financial institutions. London: Financial Times.

Saunders, A., \& Schumacher, L. (2000). The determinants of bank interest rate margins: An international study. Journal of International Money and Finance, 19(6), 813-832. http://dx.doi.org/10.1016/S0261-5606(00)00033-4

Smirlock, M. (1985). Evidence on the (non) relationship between concentration and profitability in banking. Journal of Money, Credit and Banking, 17(1), 69-83. http://dx.doi.org/10.2307/1992507

Staikouras, C. K., \& Wood, G. E. (2011). The determinants of European bank profitability. International Business \& Economics Research Journal (IBER), 3(6), 57-68. http://dx.doi.org/10.19030/iber.v3i6.3699

Sufian, F. (2009). Determinants of bank efficiency during unstable macroeconomic environment: Empirical evidence from Malaysia. Research in International Business and Finance, 23(1), 54-77. http://dx.doi.org/10.1016/j.ribaf.2008.07.002

Tariq, W., Usman, M., Mir, H. Z., Aman, I., \& Ali, I. (2014). Determinants of commercial banks profitability: Empirical evidence from Pakistan. International Journal of Accounting and Financial Reporting, 4(2), 1-22. http://dx.doi.org/10.5296/ijafr.v4i2.5939

Zuttah, B. (2004). Comparative study on banks performance of standard chartered bank and Ghana commercial bank. Harvard Business Review, 70(1), 71-79.

\section{Copyright Disclaimer}

Copyright for this article is retained by the author(s), with first publication rights granted to the journal.

This is an open-access article distributed under the terms and conditions of the Creative Commons Attribution license (http://creativecommons.org/licenses/by/3.0/). 